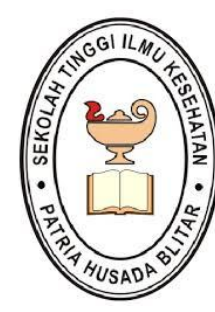

\title{
JNK
}

JURNAL NERS DAN KEBIDANAN (JOURNALOFNERS AND MIDWIFERY)

http://jnk.phb.ac.id/index.php/jnk

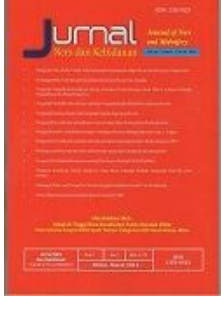

\section{The Timeliness of Baby's Basic Immunization in Pandemic Based on Mother's Knowledge about Covid-19}

\author{
Dewi Taurisiawati Rahayu
}

Bachelor of Midwifery Study Program, School of Health Sciences Karya Husada Kediri, Indonesia

\begin{tabular}{|c|c|}
\hline Article Information & Abstract \\
\hline $\begin{array}{l}\text { History Article: } \\
\text { Received, 07/04/2021 } \\
\text { Accepted, 09/08/2021 } \\
\text { Published, 10/08/2021 } \\
\text { Keywords: } \\
\text { Knowledge, Covid-19, Immunization, } \\
\text { Baby, Timeliness }\end{array}$ & $\begin{array}{l}\text { The Covid-19 pandemic situation has an impact on the implementation of } \\
\text { health services which cause delays in immunization services in health facili- } \\
\text { ties. National data showed a decrease in the basic immunization from } 55,2 \% \\
\text { in } 2018 \text { to } 53,07 \% \text { in } 2019 \text {. Meanwhile, East Java basic immunization was } \\
\text { from } 67,02 \% \text { in } 2018 \text { to } 61,33 \% \text { in } 2019 \text {. The data obtained in Blitar districts } \\
\text { showed the number of immunization was BCG of } 99,27 \% \text {, Polio of } 95,57 \% \text {, } \\
\text { measles and MMR of } 80,04 \% \text { and hepatitis B of } 98,04 \% \text {. The purpose of this } \\
\text { study was to determine the correlation between mother's knowledge about } \\
\text { Covid-19 and the timeliness of basic immunization in infants in Tulungrejo } \\
\text { Village, Gandusari District, Blitar Regency. The study used analytical obser- } \\
\text { vational method with cross sectional study approach. The independent vari- } \\
\text { able was (mother's knowledge about Covid-19) and the dependent variable } \\
\text { was the timeliness of basic infant immunization. The study was conducted } \\
\text { on } 28^{\text {th }} \text { August to } 20^{\text {th }} \text { October } 2020 \text {. in Tulungrejo Village, Gandusari District, } \\
\text { Blitar Regency. Population of } 87 \text { mothers who have babies. The sample was } \\
71 \text { respondents taken by simple random sampling technique. The instrument } \\
\text { used a questionnaire. The data analysis used the chi square test with a value } \\
\text { of } \alpha 0.05 \text {. Results : The results showed that out of } 71 \text { respondents, there } \\
\text { were } 63 \text { ( } 88.7 \% \text { ) categories of good knowledge, the timeliness of the right } \\
\text { immunization was } 62 \text { ( } 87.3 \% \text { ). Meanwhile, } 8 \text { (11.3\%) respondents with suffi- } \\
\text { cient knowledge and } 9 \text { ( } 12.7 \% \text { ) had inappropriate immunization accuracy. } \\
\text { While the chi square statistical test obtained p value }=0.001 \text { ( } \alpha<0.05 \text { ), and } \\
\text { with closeness value og } 0.371 \text { or low category.It can be concluded that there } \\
\text { was a correlation between the mother's knowledge of Covid-19 and the time- } \\
\text { liness of basic immunization in infants in Tulungrejo Village, Gandusari Dis- } \\
\text { trict, Blitar Regency. }\end{array}$ \\
\hline
\end{tabular}

(C) 2021 Journal of Ners and Midwifery

\footnotetext{
Correspondence Address:

Poltekkes Kemenkes Malang - East Java, Indonesia

P-ISSN : 2355-052X

Email: dyah_widodo@yahoo.com

E-ISSN : 2548-3811

DOI: 10.26699/jnk.v8i2.ART.p234-241

This is an Open Access article under the CC BY-SA license (http://creativecommons.org/licenses/by-sa/4.0/)
} 


\section{INTRODUCTION}

Corona virus is a new virus that can cause mild to severe illness. It is known that the corona virus originated from Wuhan-China in December 2019. Currently the corona virus is still spreading and research is still continuing. In current conditions, the corona virus is not an epidemic that can be ignored. When viewed from the symptoms, ordinary people would think that it was only limited to ordinary influenza, but for medical analysis this virus is quite dangerous and deadly. Currently in 2020, the development of this virus transmission is quite significant because its spread is worldwide and all countries are feeling the impact including Indonesia (Dashraath et al., 2020).

With the increasing number of infected people, the public is very worried about the situation. To anticipate and attempt to break the chain of the corona virus, all regions in Indonesia provide policies to limit activities outside the home, such as school activities, work from home, and even worship activities are recommended to be carried out from home. This has become a government policy based on considerations that have been maximally analyzed (Omer et al., 2020).

Due to the government's policy to limit activities outside the home, it has an impact on delayed health services such as posyandu for infants, elderly and adolescents. When the Covid-19 epidemic is in effect with restrictions on leaving the house, it makes parents hesitate and even afraid to leave and can result in low immunization coverage, and as is well known, the coverage of routine immunization in Indonesia is less than satisfactory (Diharja et al., 2020). The Covid-19 pandemic situation has an impact on the implementation of health services, causing the temporary closure or delay of immunization services at posyandu and in several other health facilities(Rahayu \& Askabulaikhah, 2020).

National data shows a decrease in the basic immunization from 55,2\% in 2018 to 53,07\% in 2019. Meanwhile, East Java is from $67,02 \%$ in 2018 to $61,33 \%$ in 2019(BPS, 2019). From data obtained in Blitar districts namely BCG of $99,27 \%$, Polio of 95,57\%, measles and MMR of $80,04 \%$ and hepatitis B of 98,04\%. (BPS, 2020). Colonel CKM dr. AchmadYurianto, Doctor and Director General of Disease Prevention and Control of the Ministry of Health of the Republic of Indonesia souece Ministry of Health in (Iswati, 2020), said that Indonesia has an immunization coverage target per province of $46.5 \%$. Meanwhile, East Java alone is only $43 \%$ with a population of around 40 million people. In June 2020, all provinces experienced a significant decrease in IDL coverage compared to June 2019 (Iswati, 2020). Some regions made a policy to postpone posyandu. For example, a circular from the Mayor of Surabaya that was forced to temporarily stop the Posyandu Toddlers. However, the Ministry of Health of the Republic of Indonesia has issued a circular letter to the heads of health offices throughout Indonesia with the subject of continuing to seek immunization according to schedule to protect babies and children from PD3I or diseases where vaccines are available to prevent them, including polio, diphtheria, and measles. If many babies do not get complete immunization, they are vulnerable to a widespread PD3I outbreak. To prevent this from happening, the immunization activities are strived to continue by following local government policies, namely byapplycontinuing tophysical distancing and other protocols such as washing hands, wearing masks, applying the principle of a minimum distance of 1 meter coupled with socializing efforts to prevent Covid-19(Iswati, 2020).

Because the government strongly recommends that basic immunization be carried out in the midst of this Covid-19 pandemic, adults mother's knowledge of the benefits of immunization and further information about Covid 19 is very important to act. According to (Notoatmodjo, 2011),knowledge is one of the components that shapes a person's attitude to action. In this case, especially in order to maximize the coverage of immunization as one of the prevention of disease outbreaks that can be prevented by immunization (PD3I) that could occur.

According to the researchers, mothers should still adhere to existing protocols to participate in posyandu activities for infants / immunizations in other places. Because epidemics of other diseases can occur if immunization is not carried out. In addition, health workers should also provide direction and education so that mothers / parents can understand how immunization should be carried out during this pandemic.

Based on the above background, researchers feel it is very important to know toddler's motherabout the problem of Covid which is associated with the timeliness of basic immunizations. Toddler mother should be on time in immunizing her baby basic immunizations contribute to determining 
the future health status of children. In the early days of life, babies are particularly susceptible to dangerous diseases, such as acute respiratory diseases, Polio, liver damage, Tetanus, Measles and many other dangerous diseases. Children affected by these diseases have a high risk of death. If not until death, attacks of viruses and diseases will cause prolonged physical and mental suffering and even biases cause disabilities.Immunization is the most powerful protection to prevent some dangerous diseases. Immunization stimulates the baby's immunity so that it can protect against some dangerous diseases such as acute respiratory diseases, polio, liver damage, Tetanus, Measles and many other dangerous diseases.So a study was conducted to determine how the correlation between mother's knowledge of Covid-19 and the timeliness of basic immunization in infants in Tulungrejo Village, Gandusari District, Blitar Regency.

\section{METHOD}

This study used a survey research that was observational analytic with a cross sectional study approach. This study consisted of 2 variables, namely the independent variable and the dependent variable. The independent variable in this study is the mother's knowledge of Covid-19. And the dependent variable is the timeliness of basic immunization in infants. The population in this study were all infant mothers in Tulungrejo Village, Gandusari District, Blitar Regency, as many as 87.To obtain samples from the population, the researchers determined the size of the sample using the slovin formulaand obtained a large sample of 71.Researchers also set inclusion criteria in this study that are toddlers who do not have serious congenital pain. Samples obtained by randomizing using the lottery. The sampling technique used was Simple Random sampling. The instrument used is a questionnaire that will be distributed to babies' mothers in the area of Tulungrejo Village, Gandusari District, Blitar Regency and checking the immunizations that have been obtained using the KIA book. This research was conducted on $28^{\text {th }}$ August to $20^{\text {th }}$ October 2020. The place used to conduct research was in Tulungrejo Village, Gandusari District, Blitar Regency. Data analysis usedChi Squaretest.

The research procedure was to visit the respondent's house to the house of the respondent who was accompanied by Posyandu cadres in each hamlet. Another method is to bring respondents to the ponkesdes. Researchers were given permission and assisted by the local midwife to collect some of the respondents at the ponkesdes. During this pandemic, it is indeed difficult to gather a large number of people. However, it has been arranged in such a way as to collect several respondents. Posyandu activities also continued during the pandemic. Once a month an immunization is held at the Ponkesdes. Of course, by still adhering to the established health protocols. All information is provided by the midwife through thegroupWhatsapp. So even though it is not face to face, information is still intertwined. However, cadres do the weighing and measuring body length by door to door. Immunization timeliness is that toddlers get immunizations according to schedule in Maternal and Child Health books. Mother's toddler come immediately to Posyandu, or the nearest health officer to complete the basic immunizations, namely Hepatitis B, BCG, Polio, DPT and Measles. Even if the toddler are coughing, cold or sedentaling, the baby can still be immunized because the baby's body is able to make immunity, so immunization is still beneficial for the baby. If the complaints increase come to the nearest health officer or doctor to get medicine. Babies taking antibiotics can also be immunized and remain beneficial to the baby.

\section{RESULT}

The presentation of the data that will be displayed are general data and special data. General data provides data on age, mother's education, infant age, infant immunization. Meanwhile, special data provides data on mother's knowledge about Covid-19 and the timeliness of immunization.

Based on the Table 1, the researched obtained that from the 71 respondents, almost all of the 67 respondents $(94.4 \%)$ were vulnerable aged $20-35$ years.

Based on the Table 4, it can be seen that from 71 respondents, almost half of the 24 respondents (33.8\%) were 4-8 months old and a small propor-

\section{Table 1. Frequency Distribution of Mother's Age}

\begin{tabular}{lc}
\hline Age & Frequency $(\%)$ \\
\hline$<20$ & $2(2,8)$ \\
$20-35$ & $67(94,4)$ \\
$>35$ & $2(2,8)$ \\
\hline Total & $\mathbf{7 1 ( 1 0 0 )}$ \\
\hline
\end{tabular}


Table 2. Frequency Distribution ofLevel Of Mother Education's

\begin{tabular}{lc}
\hline Education & Frequency (\%) \\
\hline Junior High School & $24(33,8)$ \\
Senior High School & $31(43,7)$ \\
University & $8(11,3)$ \\
\hline Total & $\mathbf{7 1 ( 1 0 0 )}$ \\
\hline
\end{tabular}

Table 3. Frequency Distribution of Infant Immunization

\begin{tabular}{lc}
\hline Immunization & Frequency $(\%)$ \\
\hline Hb 0 & $7(9,9)$ \\
BCG + Polio 1 & $10(14,1)$ \\
DPT 1 + Polio 2 & $29(12,7)$ \\
DPT 2 + Polio 3 & $13(18,3)$ \\
DPT 3 + Polio 4 & $24(33,8)$ \\
Campak & $12(16,9)$ \\
\hline Total & $\mathbf{7 1 ( 1 0 0 )}$ \\
\hline
\end{tabular}

Table 4. Frequency Distribution of Infant's Age

\begin{tabular}{lc}
\hline Infant's Age & Frequency $(\boldsymbol{\%})$ \\
\hline 0 month & $7(9,9)$ \\
1 month & $7(9,9)$ \\
2 month & $8(11,3)$ \\
3 month & $13(18,3)$ \\
$4-8$ month & $24(33,8)$ \\
9-12 month & $12(16,9)$ \\
\hline Total & $\mathbf{7 1 ( 1 0 0 )}$ \\
\hline
\end{tabular}

tion of $13(18.3 \%)$ of respondents with a baby age of 3 months.

Based on the table, the researched obtained that from the 71 respondents, almost half of the 31 respondents $(43.7 \%)$ had high school education and almost half of $24(33.8 \%)$ with last junior high school education.

Based on Table 3 it can be seen that from 71 of respondents, almost half of $4(33.8 \%)$ respondents with DPT 3 Polio 4 immunization.

Based on the results of the study, it shows that out of 71 respondents, almost all 63 respondents $(88.7 \%)$ have good knowledge about Covid -19 and a small proportion of $8(11.3 \%)$ respondents have sufficient knowledge.

Table 5. Frequency Distribution of Mothers Knowledge Level

\begin{tabular}{lc}
\hline Knowledge Level & Frequency $(\boldsymbol{\%})$ \\
\hline Good & $63(88,7)$ \\
Enough & $8(11,3)$ \\
Less & 0 \\
\hline Total & $\mathbf{7 1}$ \\
\hline
\end{tabular}

Table 6. Frequency Distribution of Timeliness of Infant Immunizations

\begin{tabular}{lc}
\hline Accuracy & Frequency (\%) \\
\hline Exact & $62(87,3)$ \\
Not correct & $9(12,7)$ \\
\hline Total & $\mathbf{7 1}$ \\
\hline
\end{tabular}

Table 7. Crosstabulation between Knowledge and Timeliness of Infant Immunizations

\begin{tabular}{|c|c|c|c|c|c|c|}
\hline \multirow{3}{*}{ Knowledge } & \multicolumn{4}{|c|}{ Accuracy } & \multirow{2}{*}{\multicolumn{2}{|c|}{ Total }} \\
\hline & \multicolumn{2}{|c|}{ Exactly } & \multicolumn{2}{|c|}{ Not Correct } & & \\
\hline & $\mathbf{F}$ & $\%$ & $\mathbf{F}$ & $\%$ & $\mathbf{F}$ & $\%$ \\
\hline Good & 58 & 81.7 & 5 & 7 & 63 & 88.7 \\
\hline Sufficient & 4 & 5.6 & 4 & 5.6 & 8 & 11.3 \\
\hline Total & 62 & 87.3 & 9 & 12.6 & 71 & 100 \\
\hline \multicolumn{7}{|c|}{ Chi square 0.001} \\
\hline
\end{tabular}

Based on the results of the research above, there were 71 respondents, almost all of $62(87.3 \%)$ had a timeliness in immunizing their babies. And a small proportion of $9(12.7 \%)$ experienced not timely immunization of their babies

Based on Table 7 it can be seen that out of 71 
respondents, $62(87,3 \%)$ of respondents had the right timing of infant immunization with good knowledge categories of $58(81,7 \%)$ and a small percentage of $9(12,6 \%)$ Respondents had inappropriate immunization timelines with good knowledge categories of $5(7 \%)$ and a small proportion of $4(5,6 \%)$ respondents had sufficient knowledge level categories.

Based on the results of thetestchi square in table 4.3, it shows that the significance value of $p$ $=$ value in chi square $p=0,001$ is smaller than $a$ $=0,05$. other than that, the closeness value was 0.371 in the low category. It was concluded that Ha was accepted and Ho was rejected, meaning that there was a correlation between the mother's knowledge of Covid-19 and the timeliness of basic immunization for infants in Tulungrejo Village, Gandusari District, Blitar Regency. The level of tightness of the correlation is low because there are other factors that affect the variablesuch as the condition of a sick child, the busyness of the parents, the delay of immunization time due to the pandemic and the other reason.

\section{DISCUSSION}

\section{Overview of Mother Knowledge About Covid- 19}

Based on the results of the study, it shows that out of 71 respondents, almost all 63 respondents $(88,7 \%)$ have good knowledge about Covid-19 and a small proportion of $8(11,3 \%)$ respondents have sufficient knowledge.

Knowledge is the result of knowing, and occurs after people sensing a certain object. Sensing occurs through the five human senses, both the senses of sight, hearing, smell, taste, and touch. Most of human knowledge is obtained through the eyes and ears.Knowledge is important for human. Something or human actions to understand the objects their face. According to (Kebung, 2017), knowledge is a term used to describe the results of someone's experience about something. In the act of knowing there are always two main elements, namely, the subject who knows (S) and something that is known or the object of knowledge $(\mathrm{O})$. The two of them are phenomenologically impossible to separate one from the other. Therefore, we can say that knowledge is the result of knowing humans. According to Notoatmodjo in (Wawan \& Dewi, 2010), a person's knowledge of an object has a different intensity or level. Broadly speaking, it is divided into 6 levels of knowledge, namely: knowledge, understanding, ap- plication, analysis, synthesis, and action. Corona virus is a group of the order Nidoviralesand thefamily Coronaviridae. Corona virus is a positive single-strain RNA virus, encapsulated and nonsegmented. Its structure forms a cube with $\mathrm{S}$ protein located on its surface. Protein S (Spike Protein) is one of the main viral antigen proteins which is the main structure of writing genes and plays a role in the attachment and entry of viruses in host cells (Sarma et al., 2020).The World Health Organization has named this virus Severe Acute Respiratory Syndrome Coronavirus-2 (SARSCoV-2) and the name of the disease as Corona Virus Disease 2019 (COVID-19).

Corona Virus Disease 2019 (COVID-19) is a new virus that emerged at the end of 2019, this virus spreads rapidly almost throughout the world, with this outbreak the Indonesian government issued an order to all Indonesian citizens to keep their distance, always wear masks and wash their hands because of the virus. This spreads through the air, in this study most of the respondents were aged 20-35 years, which means that some respondents already had a lot of experience and extensive knowledge in caring for babies and were productive about the latest issues or news and especially those related to the health of their children. News about Covid-19 is always updated every day through television news, newspapers and the internet.

Based on general data, there are respondent characteristics related to special data, namely the level of education of almost half of the respondents $(43,7 \%)$ with the last high school education. According to (Kanji et al., 2019) that the higher a person's education level, the more information he will receive, the higher the level of knowledge.

Many sources explain covid-19, and all information is received from trusted people such as the health team, local government and central government,Based on the covid-19 news delivery channel, researchers can see that there are information media and reliable sources as well as experiences experienced by respondents around, so that respondents' knowledge about Covid-19 is sufficient, this shows that sources, information media and experiences can affect a person's knowledge.

\section{Overview of Timeliness of Infant Immuniza- tions}

Based on the results of the research above, there were 71 respondents, almost all of $62(87,3 \%)$ 
had a timeliness in immunizing their babies. And a small proportion of $9(12,7 \%)$ experienced not timely immunization of their babies.

The Ministry of Health and IDAI have compiled a schedule of immunizations for children according to their age. Immunization is on an important schedule to ensure the effectiveness of the vaccine. The Covid-19 pandemic could trigger another disease pandemic due to the decrease in child immunization rates. When two or more pandemics occur at the same time, there is no unimaginable impact felt by the community.IDAI advises, if it is to delay immunization of the child, do not miss the recommendation schedule. There is a choice of catch-up immunization, immunization to pursue or complete the delayed immunization. For example, children are late or have not received the measles vaccine when they are 9-12 months old. Parents can include the child with measles immunizations in the future(Diharja et al., 2020).

Immunization comes from the word immune, immune or resistant. Children who are immunized, means that the child is given immunity to a certain disease. Children are immune or resistant to one disease but not necessarily immune to other diseases. Immunization is an effort to actively generate or increase a person's immunity against a disease, so that if one is exposed to the disease, they will not get sick or only experience mild illness (Robinson et al., 2018).According to (Sumarmi, 2017)behavior is all individual biological manifestations in interacting with the environment, starting from the most visible to the invisible behaviors, from what is felt to the least that is not felt. The results of this study show that the timeliness for immunization is still good. This is contradict previous research conducted by (Pujiasih \& Sulistyoningtyas, 2017)with the title Correlation between Mother's Work Status and Timeliness of Provision of Pentavalent Immunization and Advanced Measles in Toddlers at Paliyan Health Center. Obtaining results that most of the 71 respondents $(71.8 \%)$ did not properly carry out pentavalent immunization and advanced measles.

Based on general data there are characteristics of respondents related to the timeliness of immunization, namely education of almost half of the respondents $(43.7 \%)$ with last high school education. According to(Hikmah, 2018)an educated person will influence knowledge which later affects the person's behavior, attitudes and values .
Basic immunization is the injection of certain vaccines into the baby's body to get immunity and the baby is protected from various viruses and diseases, immunization is given according to the schedule and age of the baby, the accuracy of immunization a baby gets based on the mother or the person who cares for and cares for the baby.In This research the result that almost all respondents have received immunizations correctly, this condition can be seen from the mother's sufficient knowledge, mothers with sufficient knowledge about the importance of immunization will always bring their children for immunization. Mother's behavior, apart from being influenced by sufficient knowledge, is also influenced by the distance traveled and the role of cadres in a posyandu, the role of cadres who always informs and picks up babies who do not attend this posyandu is a good way for babies to always regularly go to the posyandu and not miss immunizations.

\section{The correlation of maternal knowledge about covid-19 to the timeliness of immunization}

The result of this study concluded that there was a correlation between the mother's knowledge of Covid-19 and the timeliness of basic immunization for infants in Tulungrejo Village, Gandusari District, Blitar Regency. The level of tightness of the correlation is low because there are other factors that affect the variable such as the condition of a sick child, the busyness of the parents, the delay of immunization time due to the pandemic and the other.

Public knowledge about Covid-19 is very important so as not to cause an increase in the number of cases of Covid-19. Immunization is an essential health service that protects individuals who are susceptible to diseases that can be prevented by immunization (PD3I). By providing immunization on time, individuals and communities will remain protected and the likelihood of an outbreak of PD3I will decrease. Preventing an outbreak of PD3I not only saves lives but also requires less resources than responding to the outbreak and helps reduce the burden on a health system that is already overwhelmed by the Covid-19 pandemic. When making efforts to continue immunization, the state must also take an approach by applying the principle of not causing harm and limiting the transmission of covid-19(Omer et al., 2020). 
Immunization services must be continued to prevent PD3I. The approach to continue running immunization services must be carried out with the principle of maintaining physical distance and adjusted to the local health system context, the local PD3I burden, status and possible local COVID-19 transmission status. If immunization services are still provided, it is very important to pay attention to infection control measures to prevent transmission of the COVID-19 virus when immunization services are provided.

During this pandemic, many parents, especially mothers, were afraid to immunize their babies because of worry and anxiety about the transmission of the Covid-19 virus. In the context of Covid-19, parents can be told that while it is important to provide immunizations on time, national and local government guidelines regarding COVID-19 prevention measures must also be followed, including maintaining physical distancing. This means the possibility of temporary disruption of immunization services. Therefore, it may be difficult to find immunization services because of physical distancing and the need to reduce crowding at health-care facilities. In such circumstances, it is important to advise parents to seek immunization for their children as soon as immunization services are available (Felicia \& Suarca,2020).

Based on previous research conducted by (Rosdiana et al., 2020)with the title Knowledge Correlation and Family Support with Timeliness of Giving Measles Immunization in PasirKaliki Bandung, the results were $(60.47 \%)$ had good knowledge, $(61.63 \%)$ had family support. good timing and timeliness of measles immunization $(60.47 \%)$. The results of the bivariate analysis result p.value to the variable knowledge 0,002 , while the variables of family support was obtained $p$-value 0,0027 then $\mathrm{HO}$ is rejected, which means there is a correlation between knowledge and family support timeliness of measles immunization. So it can be concluded that every immunization officer must provide health education and involve the family in socializing the immunization program so that the target coverage of the health programcan be achieved through the collaboration of health program officers with the community.

In the opinion of the researchers, immunization must still be given even though it is currently in the Covid-19 pandemic. Immunizations can be obtained from integrated service or doctors. How- ever, apart from that, parents must adhere to existing health protocols. The knowledge that parents / mothers have is very important. Therefore, especially medical personnel must provide education about this to the baby's parents.

In this study, most of the respondents were 2035 years old and almost half of the respondents were with high school education, in this case the respondents were mature enough to understand the existing issues and had enough experience in caring for babies. Especially in fulfilling basic infant immunization, news about corona is always broadcast Every day from all sources so that parents understand clearly about the Covid-19 pandemic. As in this study, it was found that almost all respondents already had good knowledge, but researchers found problems with respondents with good knowledge, but it was not timely to carry out basic immunizations for babies. After the researcher examined more deeply, the researcher found that there were other factors that became a barrier, namely the existence of parents who could not take their children because they were busy, some said their children were still sick. That's why researchers found that the accuracy of immunization is not only due to the corona factor or knowledge, but also influencedby the work of the mother and her baby who were sick during the immunization schedule.

\section{CONCLUSION}

The conclusion of this study is that there was a correlation between mother's knowledge of Covid19 and the timeliness of immunization for infants in Tulungrejo Village, Gandusari District, Blitar Regency.The level of tightness of the correlation is low because there are other factors that affect the variable.

\section{SUGGESTION}

For further researchersbecause this study is weak in relation, the next researchers need to be conducted research that examines other factors that affect the accuracy of the mother immunizing her baby because of the discussion of good maternal knowledge but there are obstacle factors that do not exist posyandu, empty vaccines and the other.For respondents, it can be an input for mothers to increase knowledge about current Covid-19, including protocols that must be done in an effort to prevent it and improve adherence to the timeliness of basic immunization for their babies. 


\section{REFFERENCE}

BPS. (2019). Persentase Anak Umur 12-23 Bulan Yang Menerima Imunisasi Dasar Lengkap Dengan Tingkat Kesejahteraan 40\% Terendah, Menurut Provinsi (Persen). In Badan Pusat Statistik. https:// www.bps.go.id/indikator/indikator/view_data/0000/ data/1545/sdgs_1/1

BPS. (2020). Indo_165_6355711.https://www.bps.go.id/ indikator/indikator/view_data/0000/data/1545/ sdgs_1/1

Dashraath, P., Jeslyn, W. J. L., Karen, L. M. X., Min, L. L., Sarah, L., Biswas, A., Choolani, M. A., Mattar, C., \& Lin, S. L. (2020). Coronavirus disease 2019 (COVID19) pandemic and pregnancy. American Journal of Obstetrics and Gynecology.

Diharja, N. U., Syamsiah, S., \& Choirunnisa, R. (2020). PENGARUH PANDEMI COVID 19TERHADAP KUNJUNGAN IMUNISASI DI POSYANDUDESA TANJUNGWANGI KECAMATAN CIJAMBE TAHUN 2020. Asian Research of Midwifery Basic Science Journal, 1(1), 152-165.

Felicia, F. V., \& Suarca, I. K. (2020). Pelayanan Imunisasi Dasar pada Bayi di Bawah Usia 12 Bulan dan Faktor yang Memengaruhi di RSUD Wangaya Kota Denpasar Selama Masa Pandemi COVID-19. Sari Pediatri, 22(3), 139-145.

Hikmah, N. (2018). Pengaruh Kompetensi Guru dan Pengetahuan Awal Siswa terhadap Motivasi Belajar dan Implikasinya terhadap Hasil Belajar Ekonomi Siswa. Indonesian Journal of Economic Education (IJEE), 1(1).

Iswati, R. S. (2020). ANALISIS HUBUNGAN PERAN PETUGAS KESEHATAN DENGAN CAKUPAN IMUNISASI PADA BAYI SELAMA PANDEMI COVID-19. Jurnal Ilmiah PANNMED (Pharmacist, Analyst, Nurse, Nutrition, Midwivery, Environment, Dentist), 15(3), 531-535.

Kanji, H., Nursalam, N., Nawir, M., \& Suardi, S. (2019). MODEL INTEGRASI PENDIDIKAN KARAKTER DALAM PEMBELAJARAN ILMU PENGETAHUAN SOSIAL DI SEKOLAH DASAR. JURNAL PENDIDIKAN DASAR PERKHASA: Jurnal Penelitian Pendidikan Dasar, 5(2), 104-115.
Kebung, K. (2017). Michel Foucault: Intelektual Spesifik Versus Intelektual Universal. DISKURSUS-JURNAL FILSAFAT DAN TEOLOGI STF DRIYARKARA, 16(2), 138-157.

Notoatmodjo, S. (2011). Kesehatan masyarakat. Jakarta: Rineka Cipta, 413.

Omer, S. B., Malani, P., \& Del Rio, C. (2020). The COVID19 pandemic in the US: a clinical update. Jama, 323(18), 1767-1768.

Pujiasih, K., \& Sulistyoningtyas, S. (2017). Hubungan Status Pekerjaan Ibu dengan Ketepatan Waktu Pemberian Imunisasi Pentavalen dan Campak Lanjutan pada Batita di Puskesmas Paliyan.

Rahayu, D. T., \& Askabulaikhah, A. (2020). Private Community Assistance in Antenatal Care at High Risk Pregnant Women in Public Health Center of Jelakombo Jombang. Jurnal Kebidanan Midwiferia, 6(1), 14-20.

Robinson, C. L., Romero, J. R., Kempe, A., Pellegrini, C., \& Szilagyi, P. (2018). Advisory committee on immunization practices recommended immunization schedule for children and adolescents aged 18 years or younger-United States, 2018. Morbidity and Mortality Weekly Report, 67(5), 156.

Rosdiana, E., Abdullah, M., \& Febri, Y. (2020). Jurnal Pengabdian Masyarakat (Kesehatan) Vol. 2 No. 2 Oktober 2020 Universitas Ubudiyah Indonesia. Pengabdian Masyarakat, 2(2), 100-104.

Sarma, P., Shekhar, N., Prajapat, M., Avti, P., Kaur, H., Kumar, S., Singh, S., Kumar, H., Prakash, A., \& Dhibar, D. P. (2020). In-silico homology assisted identification of inhibitor of RNA binding against 2019-nCoV N-protein (N terminal domain). Journal of Biomolecular Structure and Dynamics, 1-9.

Sumarmi, S. (2017). Model Sosio Ekologi Perilaku Kesehatan dan Pendekatan Continuum of Care untuk Menurunkan Angka Kematian Ibu. The Indonesian Journal of Public Health, 12(1), 129141.

Wawan, A., \& Dewi, M. (2010). Teori dan pengukuran pengetahuan, sikap dan perilaku manusia. Yogyakarta: Nuha Medika, 11-18. 